\title{
Effects of nutrition on residual renal functions during peritoneal dialysis
}

\author{
Periton diyalizi hastalarında beslenmenin rezidüel böbrek fonksiyonları üzerine etkileri
}

\author{
Seçil Conkar
}

Ege Üniveristesi Tıp Fakültesi, Çocuk Nefroloji ABD, İmir

\begin{abstract}
Purpose:The aim of the present study was to demonstrate the effect of nutritional management on residual renal function; and the efficacy of dialysis by providing adequate calorie supplements to Continuous Ambulatory Peritoneal Dialysis (CAPD) patients.

Materials and methods: Twelve CAPD patients followed in the Diyarbakır Children's Hospital between September 2014 and March 2015 were enrolled in the study. Nine subjects using the same type of CAPD fluid were provided with oral calorie supplements Recommended Dietary Allowance with the same type of enteral nutrition products due to inadequate calorie and protein intake. Anthropometric measurements were evaluated at baseline, month 3 , and month 6 by calculating nutritional parameters, biochemical parameters residual renal functions, and calculations of urea clearance $(\mathrm{Kt} / \mathrm{V})$ before the nutrition support.

Results: Statistically significant difference was detected in weight $(p=0.01), K t / N(p=0.03)$, and residual renal function $(p=0.01)$ starting from the 6 th month after providing nutrition support to the patients. Also CaxP value improved during month $3(p=0.01)$.

Conclusion: We believe that providing adequate calorie supplements to peritoneal dialysis patients can reduce supportive care needs, allow better preservation of residual renal function, and improve the efficacy of dialysis.
\end{abstract}

Pam Med J 2017;(1):39-44

Key words: Residual renal function, peritoneal dialysis, child, nutritional support.

Özet

Amaç:Bu çalışmanın amacı SAPD (Sürekli Ayaktan Periton Diyalizi) hastalarında yeterli kalori takviyeleri sağlayarak rezidüel renal fonksiyonlar üzerine etkinliğini göstermeyi amaçladık.

Gereç ve yöntem: 2014 Eylül ve 2015 Mart tarihleri arasında xxxxxx Hastanesinde takip edilen 12 SAPD hastası çalışmaya alındı. Yetersiz protein ve kalori alımı tespit edilen dokuz hastada aynı tip SAPD sıvıSı kullanılarak kalorili takviyeleri RDA'ya göre aynı tip enteral beslenme ürünü kullanıldı. Beslenme parametreleri başlangıçta, 3. ve 6. ayda vücut oran ölçümleri hesaplanarak değerlendirildi. Biyokimyasal parametreleri rezidüel renal fonksiyon ve total üre klirensi (Kt/V) hesaplamaları yapıldı.

Bulgular: Beslenme desteği sağladıktan 6 aydan itibaren hastalara ağırlığı $(p=0.01)$ ve rezidüel renal fonksiyonu $(p=0.01)$ ve $K t / V(p=0.03)$ istatistiksel olarak anlamlı bir fark saptandı. Ayrıca 3 . ayda CaxP değerinde belirgin iyileşme görüldü $(p=0.01)$.

Sonuç: Periton diyaliz hastaları için yeterli kalori takviyesi sağlandığında destek tedavi intiyacını azaltdığı, rezidüel renal fonksiyonları daha iyi koruma sağladığı ve periton diyaliz etkinliğini artırdığına inanıyoruz.

Pam Tıp Derg 2017;(1):31-36

Anahtar sözcükler:Kronik böbrek yetmezliği, periton diyalizi, çocuk, beslenme desteği, rezidüel renal fonksiyonlar.

Seçil Conkar

Yazışma Adresi: Ege Üniveristesi Tıp Fakültesi, Çocuk Nefroloji ABD, İzmir.

e-mail: secilcankar@yahoo.com.tr

Gönderilme tarihi: 30.06.2016

Kabul tarihi: 30.11.2016 


\section{Introduction}

Nutritional deficiency is widespread in dialysis patients. Inadequate intake of protein and energy has been found in $30 \%-40 \%$ of patients on peritoneal dialysis [1]. There are a number of factors that contribute to inadequate intake of protein and energy such as acidosis, insulin resistance, uremic toxins and loss of proteins as well as inadequate protein and calorie intake. Various factors affect the nutritional status of patients with renal failure either by interfering with one or more of the several components of protein metabolism including protein degradation and protein intake, or by protein via urine and dialysate [2]. In Continuous Ambulatory Peritoneal Dialysis (CAPD), proteins losses via dialysate can reach as 5-15 g [3]. During the past decade, various epidemiological studies in patients with renal failure and on dialysis have demonstrated a strong association among inadequate intake of protein and energy, inflammation, and increased risk of morbidity and mortality, especially in the context of cardiovascular disorders [4]. It is commonly assumed that nutritional support combined promoted with early dialysis is essential in the treatment of children with chronic renal failure [5]. Nutritional support is essential in the management of children with chronic renal failure (CRF). The present study evaluated whether nutritional support could lead to changes in the nutritional status and be associated with residual renal function, efficacy of dialysis, and the effects of reduced support on medicine treatment of patients treated by CAPD. In this study, we aimed to demonstrate the effects of nutritional support provided to CAPD patients on residual functions, efficacy of dialysis, and the need for medical therapy.

\section{Materials and Methods}

This study was done between September 2014 and March 2015. Twelve CAPD patients followed in the xxxxxx Children's Hospital were enrolled in the study. The children were asked to provide a 3-day diet record. The calorie and protein content of the diet was calculated by the same dietitian. Nine of 12 CAPD patients were detected to have lower protein-energy intake than recommended for age and weight. The study included nine patients who had been on the CAPD. None of those patients had comorbid conditions such as congestive heart failure, respiratory insufficiency, gastrointestinal disorders, chronic inflammatory, infectious, or neoplastic diseases known to further alter the nutritional status, acute inflammation such as fever or peritoneal dialysis-related infection (e.g. exit site infection, tunnel infection and peritonitis) within 6 months and on automated peritoneal dialysis (PD). All the children used the CAPD twin-bag system produced by Baxter Healthcare. Each child performed five exchanges dialysis volume of up to 1000$1500 \mathrm{~mL} / \mathrm{m}^{2}$. Clinical status of all children was evaluated in the outpatient clinics every month. All patients were dialyzed using the same type of CAPD conventional glucose fluid based peritoneal dialysis solutions (Physioneal, Baxter, 1.5\%) and performed same dialysis schedule. Nine subjects were provided with oral calorie supplements with the same type of enteral nutrition products (Isosource junior) due to inadequate calorie intake. Dietary prescriptions were based on accepted ageappropriate guidelines [6]. Patients' calorie intake for age was monitored daily by a special nutrition nurse. If the child didn't take nutritional products, the nutrition nurse was provided to give with nasogastric catheter.

Nutritional assessment included anthropometric measurements (body weight, height and body mass index). All anthropometric measurements were taken with the empty peritoneal cavity and after a thorough physical examination to assure that the patients were free of edema. Body mass index (BMI) was calculated using the formula weight $(\mathrm{kg}) /$ height $\left(\mathrm{m}^{2}\right)$. BMI, height, and weight values of all patients were evaluated according to percentile values of Turkish children [7]. Total urea clearance $(\mathrm{Kt} / \mathrm{V})$ was calculated quarterly using standard method [8]. Creatinine clearance was calculated by collecting 24-hour urine sample, using creatinine clearance $(\mathrm{ml} /$ minute $)=$ urine creatinine $(\mathrm{mg} / \mathrm{dl}) X$ daily urine volume $(\mathrm{ml}) /$ serum creatinine $(\mathrm{mg} / \mathrm{dl}) \times 1440$ formula. Participants were instructed to collect all urine during a 24-h period starting from the second urine sample on the morning of the collection day and ending with the first urine sample from the following morning. They were asked to report whether the 24-hr collection was complete and give information on whether the urine collection day was unusual for them. Anthropometric measurements (weight, height, BMI) were 
evaluated at baseline (month 0 ), month 3 , and month 6 by calculating nutritional parameters, biochemical parameters (parathyroid hormone, blood $\mathrm{Ph}$, serum creatinine, urea nitrogen, calcium, phosphate, ferritin potassium, sodium) and $\mathrm{Kt} / \mathrm{V}$.

Inadequate intake of protein and energy was defined as lower amount of intake than the recommended amount for age and gender by The KDOQI Clinical Practice Guideline for Nutrition in Children with CRF [6]. Nutrition support: Isosource Junior by Nestle was used. Content: per $1 \mathrm{ml}$ Energy $1.22 \mathrm{kcal}$, per 250 cc Protein $6.75 \mathrm{~g}$ (energy 9\%), Carbohydrate $47.5 \mathrm{~g}$ (energy 56\%), Fat $12 \mathrm{~g}$ (energy 35\%). Minerals per $100 \mathrm{cc}$ are Phosphorus $55 \mathrm{mg}$, Sodium 75 mgr, Potassium 110 mgr, Calcium 80 $\mathrm{mg}$, chlorine $80 \mathrm{mg}$, iron $1.05 \mathrm{mg}$, zinc $0.7 \mathrm{mg}$ and osmolality: $289 \mathrm{mOsm} / \mathrm{l}$. The calorie deficit was measured in $\mathrm{ml}$ by calculating the calorie requirements for age, weight, and gender [6], and supplemented with nutritional products. Nutritional charts in writing were handed to all patients. Oral feeding, which was primarily the preferred route for nutritional support or efficient enteral feeding (nasogastric), was performed. Close dietetic supervision and monitoring of nutritional intakes were maintained by monthly clinic visits, home visits, and frequent telephone contact.

This study was approved by the ethics committee of our institution and performed in accordance with the ethical standards laid down in the 1964 Declaration of Helsinki. All participants gave full informed written consent.

Statistical analysis: Data are reported as means \pm standard deviation for normally distributed variables and, as median and ranges for skewed variables not normally distributed.
One-way repeated measures analysis (ANOVA) was used to assess changes in laboratory, dialysis and nutritional parameters during follow-up (baseline, 3 and 6 months). Paired t-test was used to compare the nutritional, laboratory and dialysis parameters between baseline and at 6 months in the three groups according to the changes in body weight (gained weight, lost weight and maintained weight). Categorical variable was compared between the groups using Chi-square test. $P$ values $\leq 0.05$ were considered to be statistically significant. Statistical analysis was performed using the SPSS software (version 11.0; SPSS, Inc., USA).

\section{Results}

A total of 9 subjects were enrolled in the study (4 girls, 5 boys), (mean age, 10.1 \pm 4.7 years, range 3-15 years), who had been on CAPD for a period of 12 months to 3 years. Subjects mean weight was detected as $21.05 \pm 8.7 \mathrm{~kg}$, weightSDS (standard deviation scores) -1.47 ( -2.3 to -0.3 ), mean height as $112.7 \pm 23.4 \mathrm{~cm}$, heightSDS: -2.00 ( -2.9 to -0.3$)$ and mean body mass index (BMI) as $15.4 \pm 1.2 \mathrm{~kg} / \mathrm{m}^{2}$, BMI-SDS: -0.24 $(-1.3$ to 0.5$)$. Causes of renal failure were reflux nephropathy $(n=5)$, glomerulonephritis $(n=1)$, steroid resistant nephrotic syndrome (SRNS) $(n=1)$, nephronophthisis $(n=1)$, polycystic kidney disease $(n=1)$. Clinical characteristics of all subjects are presented in Table 1. Patients laboratory, dialysis, and nutritional parameters at baseline (month 0), month 3 and month 6 prior to nutrition support are listed in Table 2.

Improvements in body weight, $\mathrm{Kt} / \mathrm{V}$, creatinine clearance and were found at month 6 , and in CaxP value at month 3 after providing nutritional support.

Table 1. Demographic and anthropometric characteristics of the subjects.

\begin{tabular}{lr}
\hline Age year (mean) & $10.1 \pm 4.7$ \\
Gender & $5(55.5 \%)$ \\
Male $\mathrm{n}(\%)$ & $4(44.4 \%)$ \\
Female $\mathrm{n}(\%)$ & $112.7 \pm 23.4$ \\
Height $(\mathrm{cm})$ & $-2.00(-2.9$ to -0.3$)$ \\
Height-SDS & $21.05 \pm 8.7$ \\
Weight $(\mathrm{kg})$ & $-1.47(-2.3$ to -0.3$)$ \\
Weight-SDS & $15.4 \pm 1.2$ \\
Body mass index $\left(\mathrm{kg} / \mathrm{m}^{2}\right)$ & $-0.24(-1.3$ to 0.5$)$ \\
Body mass index $-S D S$ & $1625,22 \pm 369,7$ \\
The average amount of calorie calculated daily (kcal) & $29,3 \pm 12,49$ \\
The average amount of protein calculated daily (gr) & \\
\hline Normally distributed variables are expressed as the mean \pm standard deviation $(\mathrm{SD})$. & \\
SDS; standard deviation scores & \\
\hline
\end{tabular}


Table 2. Laboratory, dialysis, body composition and nutritional parameters during the follow-up of patients who were on continuous ambulatory peritoneal dialysis (CAPD) and after nutrition support at months 3 and 6

\begin{tabular}{|c|c|c|c|c|}
\hline Laboratory parameters & month 0 & month 3 & month 6 & $\mathbf{p}$ \\
\hline \multicolumn{5}{|c|}{ Body composition and nutritional parameters } \\
\hline Weight (kg) & $21.05 \pm 8.2$ & $22.7 \pm 8.8$ & $22.8 \pm 9.06$ & 0.01 \\
\hline Body mass index $\left(\mathrm{kg} / \mathrm{m}^{2}\right)$ & $15.4 \pm 1.2$ & $16.1 \pm 1.4$ & $15.7 \pm 1.4$ & 0.45 \\
\hline Height (cm) & $112.7 \pm 23.4$ & $115.9 \pm 24.3$ & $115.1 \pm 24.1$ & 0.053 \\
\hline Serum urea (mg/dL) & $113.2 \pm 79.8$ & $92.7 \pm 72.6$ & $89.0 \pm 69.5$ & 0.37 \\
\hline CaxP & $45.9 \pm 14.2$ & $40.2 \pm 10.9$ & $43.2 \pm 11.7$ & $0.01^{*}$ \\
\hline PTH & $585 \pm 23.2$ & $418 \pm 22.7$ & $295 \pm 21.5$ & 0.16 \\
\hline Blood Ph & $7.32 \pm 2.1$ & $7.35 \pm 2.3$ & $7.33 \pm 3.1$ & 0.62 \\
\hline \multicolumn{5}{|l|}{ Dialysis Parameters } \\
\hline $\mathrm{Kt} / \mathrm{V}$ & $2.50 \pm 0.79$ & $2.46 \pm 0.80$ & $2.39 \pm 0.68$ & 0.03 \\
\hline $\mathrm{CrCl}(\mathrm{mL} / \mathrm{min})$ & $7.42 \pm 2.5$ & $7.8 \pm 2.1$ & $8.7 \pm 2.9$ & 0.01 \\
\hline \multicolumn{5}{|l|}{ Nutritional parameters } \\
\hline Serum albumin (g/dL) & $3.7 \pm 0.6$ & $4.0 \pm 1.0$ & $3.8 \pm 0.6$ & 0.36 \\
\hline \multicolumn{5}{|c|}{$\begin{array}{l}\text { differences were found compared to } 6 \text { months. } \mathrm{CrCl}=\text { creatinine clearance. } \\
\mathrm{Kt} / \mathrm{V}=\text { measure of the amount of plasma cleared of urea multiplied by time }(\mathrm{K} \times \mathrm{t}) \\
\text { divided by the urea distribution volume }(\mathrm{V}) \text {. }\end{array}$} \\
\hline
\end{tabular}

\section{Discussion}

Protein-energy malnutrition is a common problem in CAPD patients $[9,10]$. The presence of inadequate intake of protein and energy is associated with increased mortality [11]. Patients in medium and high-risk groups stratified by comorbidities have poor calorie and protein intakes, and are more malnourished compared to CAPD patients in a low-risk group [12]. Another important aspect in the proper management of patients with end-stage renal disease is the provision of adequate nutrition. However, malnutrition is prevalent among patients on peritoneal dialysis and associated with higher rates of morbidity and mortality $[13,14]$. According to recent estimates, $8 \%-$ $10 \%$ and $30 \%-35 \%$ of PD patients show evidence of severe or mild-to-moderate protein-energy malnutrition, respectively [15]. Regarding nutrition, they said that "we have demonstrated a significant trend toward higher levels of serum albumin in PD patients with better glomerular filtration rate (GFR)" [16]. In addition, our study has also shown a significant and independent contribution to RRF in terms of the actual dietary intakes of protein, calories, and other nutrients in PD patients. Standard formulas should be used for short-term enteral nutrition in undernourished patients with chronic kidney disease (CKD). However; if it is thought that enteral nutrition is required for more than 5 days, then special or disease-specific formulas should be used (with reduced electrolyte and protein content) [17]. On the other hand, oral nutritional support can be provided to preserve renal functions.

Bergström et al. demonstrated that dietary protein intake is correlated with $\mathrm{Kt} / \mathrm{V}$ (urea) and $\mathrm{Kt} / \mathrm{VCr}$, and with total and renal clearances for urea and creatinine [18]. Goodship et al. said that "There was a strong correlation between $\mathrm{Kt} / \mathrm{V}$ and normalized protein catabolic rate corrected for actual weight" [19].

It is believed that providing nutrition support to PD patients is essential when their nutritional parameters are lower [17]. Oral nutrition support improves the nutritional status of malnourished patients on dialysis. However, if this administration method doesn't succeed or is not the appropriate route, nutritional support should be provided via a nasogastric (NG) tube [20]. Due to the increased incidence of peritonitis, PEG/PEJ is contraindicated in adult $\mathrm{PD}$ patients but is standard in children.

The International Pediatric Peritoneal Dialysis Network (IPPN) was established in 2007. IPPN registry is a comprehensive global database collecting patient, clinical and laboratory information on children undergoing PD at 114 centers in 40 countries around the globe. It shows that NG tube and gastrostomy feeding have beneficial effects on nutritional status as indicated by BMI SDS, in young 
infants with advanced and end-stage CKD [21]. One study suggests that the use of early nutrition support via gastrostomy buttons in combination with dialysis helps to maintain and promote growth in majority of children and hence may reduce the need for growth hormone in this population [22]. Malnutrition and growth retardation remain a major problem in patients with CKD. Thus, preventing acidosis before the development of malnutrition by adequate dialysis, removing uremic toxins, administration of parenteral nutrition support in case of inadequate oral intake through enteral or intravenous/intradialytic methods via nasogastric tube/percutaneous endoscopic gastrostomy (PEG) in the case of inadequate oral intake are the main issues at hand [23, 24].

Small solute clearance measured by $\mathrm{Kt} / \mathrm{V}$ urea is known to be one of the major determinants of dialysis adequacy. Mounting evidence has suggested that there is a strong association between $\mathrm{Kt} / \mathrm{V}$ urea values and mortality rates in dialysis populations [25]. We observed that patients on peritoneal dialysis showed significant improvements in serum, weight, $\mathrm{Kt} / \mathrm{V}$ urea and renal residual function values at month 6 and in CaxP value at month 3 .

We are of the opinion that providing adequate calorie supplements to PD patients can reduce supportive care needs, allow better preservation of residual renal functions and improve the efficacy of dialysis. To our knowledge, this is the first study to focus on nutrition support in CAPD patients and demonstrate the significance of providing adequate calorie intake. CAPD patients should be provided with nutrition support appropriate for their age and gender when the calorie intake is inadequate. As with all children, CAPD patients with absolute values should meet their calorie needs with their daily diets. However, this is not always possible owing to economic problems faced by our country like many other developing countries, which poses an obstacle to patients' adequate nutrition.

The main limitation of our study is the lack of detailed data on the prescription and actual intake of nutrients. These types of data are difficult to collect and assess accurately. This study was conducted only in CAPD patients. Therefore, we believe that larger studies performed in all pre-dialysis patients with CKD are required. These studies must include large groups of patients selected on the basis of nutritional status and protein intake. Interventional studies are needed in order to evaluate whether nutritional interventions can improve the prognosis of patients on dialysis and with renal failure.

Appropriate nutrition therapy should be planned for patients when the diagnosis of chronic kidney disease is established. In this manner, adequate nutrition can be provided, progression of the disease can be prevented, and the need for renal replacement therapy can be reduced. Nutrition therapy planning in the treatment of chronic kidney disease plays an essential role in course of the disease. Patients should be provided with nutrition support, efficient dialysis methods, close monitoring of metabolic status and the treatments that help prevent malnutrition considered as a major cause of morbidity and mortality in patients diagnosed with CKD.

Informed Consent: Written informed consent was obtained from the people who participated in this study.

Author Contributions: Concept, Design, Supervision, Resources, Materials, Data Collection and/ or Processing. Analysis and/ or Interpretation, Literature Search, Writing Manuscript; S.C

Conflict of Interest: No conflict of interest was declared by the authors.

Financial Disclosure: The authors declared that this study has received no financial support.

\section{References}

1. Tjiong HL, Swart R, van den Berg JW, Fieren MW. Amino Acid-based peritoneal dialysis solutions for malnutrition: new perspectives. Perit Dial Int. 2009;29384-29393.

2. Mastrangelo A, Paglialonga F, Edefonti A. Assessment of nutritional status in children with chronic kidney disease and on dialysis. Pediatr Nephrol. 2014;29:1349-1358.

3. Kopple JD, Blumenkrantz MJ, Jones MR, Moran JK, Coburn JW. Plasma amino acid levels and amino acid losses during continuous ambulatory peritoneal dialysis. Am J Clin Nutr. 1982;36:395-402.

4. Choi HY, Lee JE, Han SH, et al. Association of inflammation and protein-energy wasting with endothelial dysfunction in peritoneal dialysis patients. Nephrol Dial Transplant. 2010;25:1266-1271. 
5. Coleman JE, Watson AR, Rance CH, Moore E. Gastrostomy buttons for nutritional support on chronic dialysis. Nephrol Dial Transplant. 1998;13:2041-2046.

6. KDOQI Work Group. KDOQI Clinical Practice Guideline for nutrition in children with CKD: 2008 update. Executive summary. Am J Kidney Dis. 2009;53:11-104.

7. Neyzi O, Ertuğrul T. Pediatri, 3nd edn. İstanbul, Turkey, 2002;97-98.

8. Mendley SR, Umans JG, Majkowski NL. Measurement of peritoneal dialysis delivery in children. Pediatr Nephrol. 1993;7:284-289.

9. Wang AY, Sea MM, Ip R, et al. Independent effects of residual renal function and dialysis adequacy on actual dietary protein, calorie, and other nutrient intake in patients on continuous ambulatory peritoneal dialysis. J Am Soc Nephrol 2001;12:2450-2457.

10. Davies SJ, Russell L, Bryan J, Phillips L, Russell GI. Comorbidity, urea kinetics, and appetite in continuous ambulatory peritoneal dialysis patients: their interrelationship and prediction of survival. Am J Kidney Dis 1995;26:353-361.

11. Chung SH, Lindholm B, Lee HB. Is malnutritionan independent predictor of mortality in peritoneal dialysis patients? Nephrol Dial Transplant 2003;18:2134-2140.

12. Prasad N, Gupta A, Sinha A, Singh A, Sharma RK, Kaul A Impact of stratification of comorbidities on nutrition indices and survival in patients on continuous ambulatory peritoneal dialysis. Perit Dial Int. 2009;29:153-157.

13. Szeto CC, Wong $T \mathrm{YH}$, Leung $\mathrm{CB}$, et al. Importance of dialysis adequacy in mortality and morbidity of Chinese CAPD patients. Kidney Int 2000;58:400-407.

14. Churchill DN, Taylor DW, Keshaviah PR, and the CANUSA Peritoneal dialysis study group. Adequacy of dialysis and nutrition in continuous peritoneal dialysis: association with clinical outcomes. J Am Soc Nephrol 1996;7:198-207.

15. Young GA, Kopple JD, Lindholm B, et al. Nutritional assessment of continuous ambulatory peritoneal dialysis patients: an international study. Am J Kidney Dis 1991;17:462-471.

16. Wang AY, Wang M, Woo J, et al. A novel association between residual renal function and left ventricular hypertrophy in peritoneal dialysis patients. Kidney Int 2002;62:639-647.

17. Cano NJ, Aparicio M, Brunori G, et al. ESPEN guidelines on parenteral nutrition: adult renal failure. Clin Nutr 2009;28:401-414

18. Bergström J, Fürst $P$, Alvestrand A, Lindholm B. Protein and energy intake, nitrogen balance and nitrogen losses in patients treated with continuous ambulatory peritoneal dialysis. Kidney Int. 1993;44:1048-57.

19. Goodship TH, Pablick-Deetjen J, Ward MK, Wilkinson R. Adequacy of dialysis and nutritional status in CAPD. Nephrol Dial Transplant. 1993;8:1366-71.

20. Van Vlem B, Schoonjans R, Vanholder R, et al. Delayed gastric emptying in dyspeptic chronic hemodialysis patients. Am J Kidney Dis 2000;36:962-968.
21. Rees L, Azocar M, Borzych D, et al. International pediatric peritoneal dialysis network (IPPN) registry. Growth in very young children undergoing chronic peritoneal dialysis. J Am Soc Nephrol. 2011;22:23032312.

22. Coleman JE, Watson AR, Rance $\mathrm{CH}$, Moore $\mathrm{E}$. Gastrostomy buttons for nutritional support on chronic dialysis. Nephrol Dial Transplant. 1998;13:2041-2046.

23. Laville $M$, Fouque D. Nutritional aspects in hemodialysis. Kidney Int Suppl 2000;76:133-139.

24. Kopple JD. Therapeutic approaches to malnutrition in chronic dialysis patients: The different modalities of nutritional support. Am J Kid Dis 1999;33:180-185.

25. Churchill DN, Thorpe KE, Nolph KD, Keshaviah PR, Oreopoulos DG, Page D. Increased peritoneal membrane transport is associated with decreased patient and technique survival for continuous peritoneal dialysis patients. The Canada-USA (CANUSA) Peritoneal dialysis study group. J Am Soc Nephrol 1998;9:1285-1292. 